\title{
PROBLEM METODOLOGIS DALAM STUDI HUKUM ISLAM
}

\author{
Iin Solikbin*
}

\section{Abstract}

The effort to apply God's revelation creates a dispute between the revilation itself and the social context. Usul figh as an understanding method which has divine texts as starting points is adjusted to the future and based on God's revelation by doing ÿthihad. Usulfiqhdevelopessignificantly in trandating those revelation in accordance with society demand, place and condition.

Kata Kunci: Hukum Islam, Usul Fikih, Problem Metodologis.

\section{A. Pendahuluan}

Reading the Qur'an in tandem with early Islamic history remains for muslims both an act of piety and an interpretative challenge. How does one respond in successive eras to divine revelation? Is submission to the will of God best accomplished by conforming to the patterns of earlier epoch? Or does one have to search a new for the spirit of God's directive and Muhammad's eaxample and try to apply their guidance to today's challenges? ${ }^{1}$

Kutipan tersebut menggambarkan bahwa umat Islam dan juga umat agama lain selalu dihadapkan pada tarik-menarik antara dua kutub ekstrem berupa wahyu yang tidak pernah berubah dan realitas sosial yang cenderung berubah. Sejarah menunjukkan bahwa umat Islam

Penulis adalah dosen tetap Jurusan Syariah STAIN Purwokerto, alumnus Program Pascasarjana (S2) IAIN Imam Bonjol Padang.

'Norman Anderson, Law Reform in The Muslim World (London: University of London The Athlen Press, 1976), hal. 37. 
selalu berusaha memahami inti pesan wahyu Allah dalam kerangka menjawab persoalan umat yang cenderung berubah dan hal ini telah melahirkan sejumlah tawaran konsep sekaligus aplikasinya yang tidak selalu sama, tidak terkecuali dalam lapangan hukum Islam baik pada dataran metodologis (usul fikih) maupun aplikasinya (fikih).

Dalam konteks hukum Islam, setelah melalui abad pertengahan yang cenderung konservatif dan menolak adanya perubahan, para ahli hukum Islam (jurists, fuqahà) abad modern semakin menyadari bahwa perubahan baik melalui proses reformasi (ị̦lāb) maupun pembaruan $(\text { tajdid) })^{2}$ merupakan satu hal yang tidak bisa dielakkan (inevitable). Pada mulanya, perubahan itu dilakukan dengan mengadopsi hukum-hukum Barat terutama yang berasal dari Perancis, Jerman, Swiss, dan Belanda. Sedangkan pembaruan tahap berikutnya dilakukan dengan mengkaji kembali persoalan metodologis (usul fikih)yang dipandang sebagai dasar dalam penetapan hukum Islam.

\section{B. Pergeseran Orientasi dalam Studi ke-Islaman 1. Hukum Agama dan Hukum Sekuler}

Dalam literatut hukum dikenal dua kategori hokum yang berbeda secara substansial dengan hukum agama (baca: hukum Islam) ${ }^{3}$ dan hukum sekuler (baca: bukum Barat). Seringkali dinyatakan bahwa hukum agama bersifat pasti dan kebenarannya bersifat absolut dengan model

${ }^{2}$ Pembankan dipakai sebagai padanan kata tajdid, reformasi (ișah) yang berarti pikiran, aliran, gerakan, dan usaha untuk merubah paham-paham, adat istiadat, institusi-institusi lama, dan sebagainya untuk disesuaikan dengan suasana baru yang diakibatkan oleh kemajuan ilmu pengetahuan dan teknologi modern. Penggunaan istilah ini lebih lengkap lihat, Harun Nasution, Pembaharuan Dalam Idam: Sejarah, Pemikian, dan Gerakam, (Jakarta: Bulan Bintang, 1994), hal. 4. Lihat juga Ridwan Lubis, Perspektif Pembaharuan Pemikiran Islam, (Medan: Pustaka Widyasarana, 1993), hal. 4. Awad Bahasoan, "Gerakan Pembaharuan Islam: Interpretasi dan Kritik," dalam Prima 1984, hal. 106-129.

${ }^{3}$ Istilah hukum Islam muncul belakangan sebagai terjemahan dari Ilamic law yang secara teknis banyak dipakai untuk menggantikan istilah shariah. Shariab dan hukum Islam, fiqh merupakan istilah-istilah yang banyak dïdentikkan penggunaannya walaupun secara etimologis ketiganya berbeda satu sama lain. Tentang perkembangan terminologi ketiga istilah 
pendekatan yang cenderung normatif-deduktif. Sedangkan hukum' sekuler kebenarannya bersifat realtif dengan model pendekatan yang cenderung empiris-induktif dan karena itu bersifat ilmiah. Sejalan dengan ini, maka dikatakan bahwa tidak seperti hukum sekuler, hukum agama dan terlebih hukum Islam tidak mengenal perubahan (immutable) bahkan perubahan dikatakan sebagai satu pengingkaran terhadap ajaran agama itu sendiri.

Pemahaman seperti itu terekam luas dan terdokumentasi rapi di kalangan para ahli hukum, terutama setelah munculnya karya-karya para orientalis, khususnya masa-masa awal lahirnya kajian hukum Islam di kalangan mereka. Hal ini terjadi karena menurut kaum orientalis, Islam merupakan satu agama yang berbeda dengan agama-agama lain di dunia (adistinctreligion), dan pandangan tersebut dikritik oleh Khalifah Abdul Hakim dengan mengatakan:

generally, people in the west think that Islam is a spesial kind of religion with certain distintive dogmas preached by Muhammad. It will help us in the subject of our natural law if you (the orientalis) at the outset, remove that great misunderstanding from your minds. ${ }^{4}$

Sebenarnya hingga batas-batas tertentu, pemahaman sejumlah orientalis tersebut tidaklah terlalu salah. Sebab karya-karya mereka merupakan hasil penelitian terhadap karya-karya dan sekaligus kehidupan umat Islam di sejumlah negara-negara muslim, terutama pada masa akhir abad pertengahan hingga masa pra-modern yang seringkali dikenal dengan jom $\bar{d}$ atau the dark age ketika umat Islam mengalami titik terendah yang ditandai dengan merajalelanya taklid buta. ${ }^{5} \mathrm{Hal}$ ini terlihat, misalnya pada sikap fanatik mazhab umat Islam

ini, lihat Ahmad Hassan, The Earty Development of Islamic jurisprudence, (Delhi: Adam Publishers and Distributors, 1987), hal. 2-8. Amir Syarifuddin, Pembaharuan Pemikiran dalam Huketm Ilam, (Padang: Angkasa Raya, 1993), hal. 13-20.

‘Dikutip dari Akh. Minhaji, "Reorientasi Kajian Usul Fiqh,” dalam Al-Jamiah:Jaornd of Elamic Studies No. 63/VI/1999, hal. 15-17.

5Lihat, Ziauddin Sardar, Jihad Intelektual: Merumuskan Parameter-parameter Sains, terj. A.E. Priyono (Surabaya: Risalah Gusti, 1998), hal. 36. 
yang memandang bukan hanya hukum Islam tidak bisa berubah tetapi juga hukum yang ditentukan oleh masing-masing madzhab tersebut dipandang sebagai satu kebenaran mutlak oleh masing-masing pengikutnya. Karena itu sangat tepat ketika Mazheruddin Siddiqi mengatakan: kekakuan pikiran-pikiran kaum ortodoks telab membuat umat Islam tidak mampu melihat bukum secara dinamis dan terkungkung oleb ulama masa lalu yang pikirannya dipandang sakral dan tidak dapat diganggugugat (infallible). ${ }^{6}$

Dengan fenomena di atas, maka wajar apabila perubahan hukum dalam Islam kemudian menjadi topik menarik dikalangan umat Islam, bahkan hingga kini hal tersebut masih menjadi kontroversi antara pendukung perubahan dan yang menolaknya. Hal ini kemudian diperparah oleh salah paham terhadap doktrin al-rujî̀' ila al-Qur'än wea alsumnah yang dipahami sebagai looking backevard sebagai kebalikan dari orientasi berfikir modern yang menerapkan prinsip looking forreard.

Persoalannya tidak berhenti sampai di situ, hingga saat ini peralihan dari apa yang disebut dengan religious society menjadi secular society yang dalam ilmu sejarah ditandai antara lain dengan pergeseran dari providential theory menuju progress theory kurang mendapat perhatian. Padahal, peralihan ini berimplikasi jauh termasuk dalam bidang kajian hukum agama (baca: hukum Islam). Misalnya, pada abad pertengahan perbedaan agama menjadi sangat penting dalam menentukan hampir semua persoalan masyarakat, karena itu sejarah Islam mengenal apa yang disebut dengan dzimmi, där al-Islâm, dan där al-harb. Tokoh dan institusi agama (seperti sistem dergy dan juga ulama) menjadi sistem sentral dalam masyarakat. Setelah munculnya masyarakat sekuler, perubahan antara seseorang dengan orang lain bukan lagi ditentukan oleh agama yang dianut tetapi lebih pada kewarga-negaraan mereka, terutama setelah munculnya nation state? Akibatnya, penetapan segala

\section{'Minhaji, "Reorientasi," hal. 16.}

'Abdullah Ahmad an-Na'im mengupas persoalan-persoalan isu HAM dan hukum publik dalam bukunya Tawards in Ilamic Reformation: Civil libertie, Hsoman nights and International law, (New York Syracuse University Press, 1990). Menurut an-Na'im dalam menghadapi isu-isu HAM dan hukum publik diperlukan transformasi pemahaman al-Qur'an dari Madanijaboriented menuju Makkryab-oriented. 
sesuatu yang semula didominasi oleh pertimbangan agama kemudian bergeser pada pertimbangan kewarganegaraan.

\section{Antara Normatif-Deduktif dan Empiris-Induktif}

Salah satu persoalan krusial dalam bidang kajian hukum Islam adalah adanya tarik menarik antara model pendekatan normatifdeduktif (ilâbiyyah, theocentris, subjective theological transendentalism) dan empiris-induktif (insâniyyah, anthropocentris, rational cum-empirical justification). Pendekatan normatif-deduktif cenderung didominasi oleh Aristotelian logic yang bercirikan dichotomis-absolutistis-spiritualistic-logic. Dengan model logika demikian, maka usul fikih cenderung mendekati masalah secara hitam putih, benar salah, halal haram, dan semacamnya. Akibatnya pemikiran yang ada bersifat sempit, kaku, dan menolak nuansa-nuansa yang berada di luar dua kutub ekstrem tersebut. ${ }^{8}$

Di sisi lain pendekatan empiris-induktif menunjukkan gejala yang berbeda, jika tidak bertentangan. Model ini lebih bernuansa Hegelian logic yang bercirikan dialectical logic. Berdasarkan logika Hegel ini, maka every one them and is right within is owe field. Artinya, kebenaran itu bersifat realtif dan dipengaruhi oleh asumsi-asumsi dasar yang dianut dan juga dialektika sosial yang terjadi. Dengan demikian hasil ketentuan hukum dengan model pendekatan yang demikian bersifat realtif, dan diyakini bersifat luwes, fleksibel sekaligus dipandang mampu mengikuti denyut jantung dan perkembangan masyarakat dengan tetap berlandaskan pada prinsip-prinsip yang ada. Model ini sama dengan model-model kajian ilmu pengetahuan lainnya yang dikenal dengan scientific approach dengan hasil yang bersifat relatif.'

Kedua model tersebut di atas selayaknya mendapat perhatian mereka yang menekuni kajian usul fikih. Sebab hal tersebut mempunyai implikasi terhadap perlunya mencermati sejumlah kajian usul fikihyang

${ }^{8}$ Lihat Atho Mudzhar, Membaca Gelombang Itihad: Antara Tradisidan Liberass, (Yogyakarta: Titian Ilahi Press, 1998), hal. 61-70.

"Joseph Schacht, "Problem of Modern Islamic Legislation," dalam Ilamic Law and Legal Theory, ed. Ian Edge (Aldershot: Dantmouth Publishing Company, 1996), hal. 512-517. 
berkembang saat ini. Bahkan menurut sebagian ahli hukum Islam, model kajian empiris-induktif masih menyimpan misteri besar. Paling tidak, model empiris-induktif cenderung tidak menempatkan teks (alQur'an dan Hadis dan bukan teks dalam pengertian hermeneutik) sebagai titik berangkat awal dalam satu analisa persoalan hukum, tetapi sebaliknya berangkat dari fenomena dan interaksi sosial atau sesuatu yang dapat diindera. Jika demikian, model ini cukup sulit untuk dicerna bagi yang terbiasa dengan model pendekatan dan pola normatifdeduktif. Akibatnya, sebagian orang bisa saja bertanya, apakah pendekatan empiris-induktif yang dalam analisanya tidak berangkat dari teks kitab bisa digolongkan pada apa yang secara tradisional disebut dengan usul fikih? Persoalannya tidak berhenti sampai di situ. Barangkali sebagian orang tidak keberatan jika non-muslim mengkaji hukum Islam dengan model kedua (baca: empirisinduktif) melalui scientific approad. Namun, apakah mereka juga bisa masuk pada model kajian pertama (baca: normatifdeduktif). Dalam konteks inilah bisa dipahami keberatan orang muslim jika non-muslim seperti orientalis (outsider) memasuki kajian-kajian ke-Islaman. Fazlur Rahman mendukung pandangan demikian dengan mengatakan bahwa untuk mengkaji suatu agama, seorang outsider hanya bisa memasuki pada level intellectual undersanding atau kajian ilmiah sebagaimana dikenal di Barat. ${ }^{10}$

Berdasarkan pertimbangan di atas, seorang muslim tentunya bisa memasuki kedua model pendekatan tersebut. Bahkan nampaknya suatu keharusan bagi mereka untuk mengkombinasikan kedua pendekatan guna mendapatkan hasil ijtihad hukum yang maksimal. Dengan demikian mereka mampu merealisasikan pesan-pesan ilahiyah sekaligus memenuhi tuntutan umat sesuai dengan tempat dan masa. Dan ini sekaligus diharapkan bisa memberikan sumbangsih berarti terutama menghadapi peralihan dari religious society menuju secular society.

${ }^{10}$ Sardar, Jihad Intelektual, hal. 87. 


\section{Makna dan Posisi Usul fikih}

Secara literal usul fikih merupakan jamak dari kata $u s \underline{u} l$ yang berarti dasar-dasar, pokok-pokok, ataupun landasan-landasan. Sedangkan figh arti dasarnya fabm, pemahaman. Dengan demikian, secara etimologis usul fikih dapat diartikan sebagai dasar-dasar pemahaman figh ( $m \bar{a}$ yubnā 'alaybi fiqh). Berangkat dari pengertian etimologis ini, maka dapat dipahami bahwa usul fikih merupakan satu ilmu yang mempelajari dasar-dasar, metode-metode, pendekatanpendekatan, dan teori-teori yang digunakan dalam memahami fikih. Ini berarti menempatkan usul fikih pada posisi sentral dalam studi keislaman dan seringkali disebut sebagai the queen of Islamic sciences. Dalam bahasa Ṭahā Jäbir al-'Alwāni:

isull al-figh is rightly considered to be most important method of reseach ever devised by muslim thought. Indeed, as the solid foundation upon which all Islamic disciplines are based, $\iota \varsigma \bar{u}$ al alfigh not only benefited Islamic civilization but contributed to the intellectual enrichment of world civilization as a whole. ${ }^{11}$

Sejalan dengan ini Sahal Mahfudz mengatakan: "fiqh merupakan formulasi pemahaman Islam yang digali dari al-Qur'an dan al-Hadits... Fiqh dimaksudkan agar tiap individu dapat membangun perilaku berdasarkan akidah, syari'ah, dan akhlak." ${ }^{12}$ Jadi tampaknya tidak berlebihan jika ada yang mengatakan bahwa ilmu pertama yang memberikan kerangka dasar memahami ajaran Islam pada masa awal Islam adalah usul fikih.

Banyak pemikir Muslim memandang metodologi (baca: usul fikih klasik) tanpa cacat epistemologis apapun. Ajakan sejumlah ulama untuk mengubah pola bermadzhab dari yang qaueli ke manhaīi mengandung pengertian bahwa metodologi klasik yang telah dikerangkakan oleh para ulama dahulu memang sudah tuntas dan sempurna. Sehingga, kewajiban umat yang akan datang kemudian bukan untuk

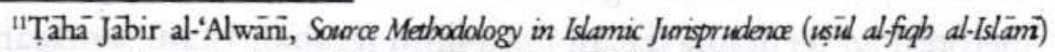
(Virginia: International Institute of Islamic Thought, 1994), hal. 2.

${ }^{12}$ Sahal Mahfudz, Nuansa Fiqh Sosial, (Yogyakarta: LKiS, 1994), hal. 12. 
mengubahnya, tetapi mengkuti dan melaksanakannya. Di sini, sebuah metodologi yang sejatinya lahir dari pabrik intelektualitas manusia yang nisbi telah diposisikan sebagai sesuatu yang mutlak dan tak terbantah. Mereka telah melakukan idealisasi dan universalitasisasi terhadap metodologi lama yang provisionaris

Mestinya, metodologi Islam (baca; usul fikih klasik) diletakkan dalam konfigurasi dan konteks umum pemikiran pada saat formatifnya. Sebab, fakta akademis kontemporer seringkali manayangkan ketidakberdayaan bahkan kerapuhan metodologi (baca: usul fikih klasik) tersebut.

1) Metodologi (baca: usul fikih klasik) terlalu memandang sebelah mata terhadap kemampuan akal publik di dalam menyulih dan menganulir ketentuan-ketentuan legal formal di dalam Islam yang tidak lagi relevan. Ditegaskan bahwa ketika terjadi pertentangan antar akal publik dan bunyi harfiah teks ajaran, metodologi lampau selalu mangambil cara penundukan terhadap akal publik.

2) Metodolog (baca: usul fikih klasik) kurang tanggap terhadap kemampuan manusia di dalam merumuskan konsep kemaslahatan, walau untuk umat manusia sendiri. Manusia tidak memiliki reputasi dan kedudukan apapun dalam ruang usul fikih (klasik), kecuali sebagai sasaran hukum yang tak berdaya (mukallaf).

3) Aktivitas ijtihad selalu digerakkan di dalam teks. Ijthad yang tidak berkulminasi pada teks adalah ilegal, sebab teks merupakan aksis dari seluruh cara pemecahan problem.

Tentu saja ini merupakan kelemahan metodologis tersendiri yang mesti mendapatkan perhatian. Dengan merekonstruksi kaidahkaidah uul, niscaya produk yang dihasilkan akan lebih solutif bagi problem-problem kemanusiaan. Karena, betapapun bagusnya sebuah metodologi, jika kandas pada tingkat pemecahan problem, maka ia tidaklah banyak guna dan manfaatnya. Kecanggihan sebuah metodologi terutama dalam ilmu-ilmu terapan Islam semacam usul fikih, akan berkoresponden secara pasti dengan pewujudan 
kemaslahatan bagi sebesar-besarnya umat manusia.

\section{Al- Tbrab bi al-Maqāṣid lā bi al-Alfāzz}

Kaidah ini berarti bahwa yang harus menjadi perhatian seorang mujtahid di dalam menginstinbatkan hukum dari al-Qur'an dan alSunnah bukan huruf dan teksnya melainkan maqūsid (tujuan hukum) yang dikandungnya. Yang menjadi aksis adalah cita-cita etik-moral dari sebuah ayat dan bukan legislasi spesifik atau formulasi literalnya. ${ }^{13}$ Untuk mengetahui maqāsid, maka seseorang dituntut untuk memahami konteks, yaitu bukan hanya konteks personal yang juz is-partikular melainkan juga konteks impersonal yang kulli-universal. Pemahaman tentang konteks yang lebih dari sekedar ilmu sabab al-nuzül dalam pengertian klasik itu merupakan persyaratan utama untuk menemukan maqūs șd al-shariab. ${ }^{14}$

Al-Shāțibỉ di dalam al-Murwäfaqāt mendengungkan sebuah pernyataan genial bahwa seorang mujtahid diharuskan untuk melengkapi diri dengan pengetahuan yang memadai menyangkut tradisi dan kebiasaan masyarakat Arab sebagai masyarakat awal yang menjadi sasaran wahyu. Pengetahuan tentang konteks tentu bukan untuk konteks itu sendiri, melainkan untuk mengambil dan memperoleh prinsip-prinsip dasar Islam atau yang dikenal dengan istilah maqūsid alshari'ah. ${ }^{15}$ Begitu maqāsid al-shari'ah sudah dicapai, maka teks harus segera dilepaskan dari konteks ke-arabannya (dekontekstualisasi) untuk kemudian dilakukan rekontekstualisasi, yaitu menerapkan prinsip-prinsip dasar Islam sesuai dengan tempat dan keadaan, Maka kontekstualisasi, dekontekstualisasi, dan rekontekstualisasi merupakan mekanisme kerja penafsiran sepanjang masa.

Dalam usul fikih, maqūsid al-shari'ab itu adalah keadilan, kemaslahatan, hikmah kebijaksanaan, dan cinta kasih. ${ }^{16}$ Maqäsid inilah yang

${ }^{13}$ Muhammad Khalid Mas'ud, Islamic Legal Philosophy: A Study of Abu Ishaq al-Shatibi, Life and Thought (Delhi: International Islamic Publisher, 1989), hal. 225.

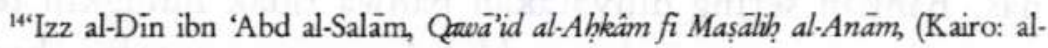
Istiqämah, t.t.), hal. 129.

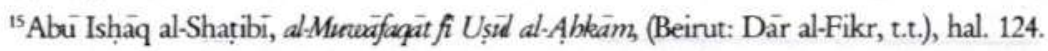

${ }^{16}$ Mas'ud, Elamic legal, hal. 187. 
sejatinya menjadi sumber inspirasi ketika al-Qur'an menetapkan ketentuan-ketentuan legal-spesifik. Dengan kata lain, maxāsid al-sharỉah adalah sumber dari segala sumber hukum dalam Islam, termasuk sumber dari al Qur'an sendiri.

Kaidah di atas merupakan antipoda dari kaidah al-ibrab bi kbusūus al-lafzî, là bi 'umūm al-sabab, yaitu bahwa yang harus menjadi pertimbangan adalah kekhususan lafaz, bukan keumuman sebab. Maka, jika suatu nas menggunakan redaksi yang bersifat khusus, maka tidak ada pilihan lain selain menerapkan nas tersebut, sekalipun nas itu hadir untuk merespons suatu peristiwa yang khusus

Ada banyak kritik terhadap kaidah ini. Pertama, kaidah ini dipandang terlalu berorientasi pada semantik dengan menafikan peranan sabab al-nuzūl. Implikasinya, kaidah ini kerap terjebak pada suatu pernyataan, bahwa semakin harfiah seseorang membaca al-Qur'an, maka semakin dekat ia pada kebenaran. Sebaliknya, semakin jauh dari makna literal al-Qur'an, maka ia semakin jauh pula dari kebenaran.

Kedua, kaidah ini, realitas hendak disubordinasikan ke dalam bunyi literal teks, yaitu yang dituju adalah kebenaran teks dengan konsekuensi mangabaikan konteks (al-siyāq al-tānkkhi) yang mengitari. Konteks didudukkan dalam posisi yang rendah dan sekunder, sehingga analisis terhenti hanya pada konteks linguistik dan ini tidak akan cukup memadai untuk mengejar kebenaran hakiki (maāișid asāsijyab) yang diusung oleh teks. Analisis seharusnya dilanjutkan pada penyingkapan makna yang terdiamkan (al-maskît'anb), yaitu makna yang tercakup secara verbatim di dalam aksara sebuah teks.

\section{Jazwāz Naskb al-Nuṣuṣ bi al-Maṣlaḥab}

Dalam ranah usul fikih, jika terjadi pertentangan antara teks (nas) dan maṣlahah, umumnya mengatakan bahwa yang dimenangkan adalah nas, Bahkan sering dinyatakan bahwa tidak mungkin terjadi pertentangan antara nas dan mașlahah, karena apa yang diujarkan oleh

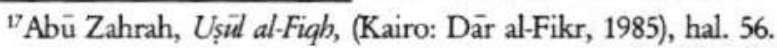


nas adalah kemaslahatan itu sendiri. ${ }^{17}$ Sering disinyalir bahwa kemaslahatan yang diandaikan oleh manusia adalah kemaslatan relatif sementara kemaslatan yang ditetapkan nas adalah kemaslahatan hakiki dan obyektif. Kewajiban manusia adalah mengamalkan dan mengimaninya secara sepenuh hati. Sejatinya maslaḅah memiliki otoritas untuk menganulir ketentuan-ketentuan teks. ${ }^{18}$ Inilah yang dimaksud dengan ungkapan naskh al-nuṣūs bi al-mașlahạh. ${ }^{19}$ Dengan cara ini, maka cita kemaslahatan akan senantiasa berkreasi untuk memproduksi formulasi di tengah kegamangan dan kegagapan formulasi teks keagamaan. Praktek dari kaidah ini dapat diketahui dari pembatalan demi pembatalan terhadap sejumlah hukum Islam, yang dikenal dengan istilah naskh.

Teks suci tanpa kemaslahatan memang tak berfungsi apa-apa buat manusia, kecuali untuk teks itu sendiri. Teks baru bermakna sekiranya menyertakan cita kemaslahatan bagi umat manusia. Kemaslahatan adalah fondasi paling pokok dari setiap perundangundangan Islam. Ini bukan karena ajaran Islam memang perlu dicocokcocokan secara opurtunistik dengan perkembangan kemaslahatan, melainkan karena tuntutan kemaslahatan itu secara obyektif meniscayakan demikian. ${ }^{20}$ Menarik pernyataan 'Izz al-Din ibn 'Abd al-

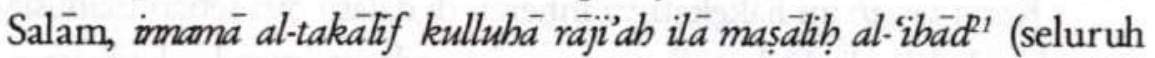
ketentuan agama diarahkan untuk sebesar-besarnya kemaslahatan umat manusia). Dengan ini, maka kemaslahatan merupakan ajaran agama yang thawabit (tidak berubah, pokok, dan universal), sementara wujud pelaksanaan cita kemaslahatan itu merupakan perkara agama yang mutaghayyir (berubah-berubah mengikuti perubahan alur sejarah dan peradaban).

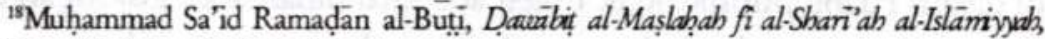
(Kairo: Där al-Sa'ad, t.t.), hal. 45-47.

${ }^{19}$ Abdullahi Ahmed an-Na'im, Towands in Idamic Reformation: Crvil libertie, Human rights and International law, (New York Syracuse University Press, 1990), hal. 75.

${ }^{20}$ Muștafa Zayd, al-Mașlaḥah fi al-Tasbri' al-Islāmi wa Najm al-Din al-Ț ugf, (Kairo: Där alFikr al-Arābi, 1974), hal. 75.

${ }^{21}$ Izz al-Din ibn 'Abd al-Saläm, Queväid al-Ahkäm, hal. 125. 


\section{Yajūzu Tanqiḥ al-Nușūs bi al-mașlaḥah}

Kaidah ini hendak menyatakan bahwa akal publik memiliki kewenangan untuk menyulih dan mengamandemen sejumlah ketentuan dogmatik agama yang menyangkut perkara-perkara publik. Sehingga ketika terjadi pertentangan antara akal publik dengan bunyi harfiah teks, maka akal publik berotoritas untuk mengedit, menyempurnakan, dan memodifikasikannya. Modifikasi initerasa sangat dibutuhkan ketika berhadapan dengan ayat-ayat partikular, seperti ayat hudüd (seperti potong tangan, rajam, dan sebagainya), waris dan sebagainya. Ayatayat tersebut dalam konteks sekarang, alih-alih bisa menyelesaikan masalah-masalah kemanusian, yang terjadi justru merupakan bagian dari masalah yang harus dipecahkan melalui prosedur tanqih yang berupa taqyïd bi al-áql, takbșis bi al-aql, dan tabyin bi al-aql.22

Ayat-ayat semacam ini, sepenuhnya merupakan respons al-Qur'an terhadap kasus-kasus tertentu yang berlangsung dalam lokus tertentu pula, masyarakat Arab. Dalam tataran ini, universalisasi al-Qur'an tanpa melalui proses tanqüh harus dihindari. Sebab, membiarkan al-Qur'an persis seperti dalam bunyi harfiahnya hanya akan mengantarkan al-Qur'an pada perangkap yang mematikan spirit dan elan vital al-Qur'an.

Kerja tanqüh ini hakekatnya inheren di dalam diri setiap manusia yang berakal budi. Dalam jiwa manusia terdapat impuls abadi yang tidak pernah padam untuk ber-tanqị. Terdapat dorongan adekuat untuk senantiasa berpihak pada kebenaran dan keadilan. Selalu ada kecenderungan untuk mengoreksi pelbagai kekeliruan dan menyempurnakan segala kekurangan. Akal publik dan akal privat ini dibutuhkan tentu untuk menghindari oligarki pendapat atau otoritarianisme dalam merumuskan dan memecahkan urusan-urusan publik. Bagaimanapun di dalam ruang publik tidak boleh ada satu pihak atau golongan dalam masyarakat yang berhak memaksa pandangannya pada orang lain, karena pandangannya dinilai lebih benar. Mereka memiliki kedudukan dan derajat yang sama.

${ }^{2}$ Mahmud Muhammad Toha, The Second Mexsageof Islam (New York Syacuse University Press, 1989), hal. 45. 
Pandangan di atas sangat berbeda dengan pandangan mainstream yang terus menerus mendevaluasi akal di bawah teks. Sejatinya akal publik harus diberi posisi yang penting. Akal publik tidak cukup hanya tampil sebagai pengelola data-teks. Menyangkut perkara-perkara mu'amalah, akal publik perlu mendapatkan wewenang untuk mengevaluasi efektivitas dan kinerja beberapa ketentuan al-Qur'an dan al-Hadits di dalam mengimplementasikan maxāsid al-shariah di bumi realitas. Sekiranya dari data lapangan diketahui ketidakberdayaan sebuah teks di dalam mengatasi perkara-perkara publik, maka akal publik mesti mempertibangkan ulang ketentuan tersebut. Akal publik bertugas untuk mengeluarkan spirit dasar Islam dari lipatan teks agama. Akal publik mempunyai tanggung jawab moral untuk men- tanqỉ ayatayat yang problematik.

\section{Penutup}

Adanya upaya tarik menarik antara teks tertulis dengan realitas sosial dalam menghadapi persoalan tersebut. Pada waktu yang sama sebagaimana ilmu pengetahuan yang lain usul fikih mengalami perkembangan dan perlu untuk selalu dievaluasi berdasarkan perkembangan dan tuntutan masyarakat.

\section{DAFTAR PUSTAKA}

'Abd al-Salām, 'Izz al-Din ibn. Quwäid al-Ạbkämfi Mașälị al-Anām. Kairo: alIstiqāmah, t.t.

Abū Zahrah, Muhammad. Ușül al-Figh. Kairo: Dār al-Fikr, 1985.

Al-'Alwani, Taha Jabir. Source Methodology in Islamic Jurisprudence (Ușül al-Figh alIsläm). Virginia: International Institute of Islamic Thought, 1994.

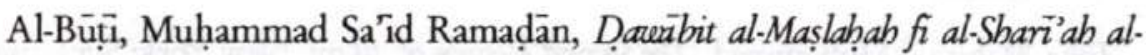
Islämizyah. Kairo: Dār al-Sa'ad, t.t.

Al-Shāțibì, Abū Ishạāq. Al-Muwwäfaquāt fi Ușūl al-Aḥkām. Beirut: Dar al-Fikr, t.t. 
lin Solikhin

An-Na'im, Abdullahi Ahmed. Tawardsin IslamicReformation: Civilliberties, Human rights and International law. New York Syracuse University Press, , 1990.

Anderson, Norman. Law Reform in The Muslim World. London: University of London The Athlen Press, 1976.

Awad, Bahasoan. "Gerakan Pembaharuan Islam: Interpretasi dan Kritik," dalam Prisma 1984.

Hassan, Ahmad. The Early Development of Islamic Jurisprudence. Delhi: Adam Publishers and Distributors, 1987.

Lubis, Ridwan. Perspektif Pembaharuan Pemikiran Islam. Medan: Pustaka Widyasarana, 1993.

Mahfudz, Sahal. Nuansa Figh Sosial, Yoyakarta: LKiS, 1994.

Mas'ud, Muhammad Khalid. Islamic Legal Philosophy: a Study of Abu Ishaq alShatibi: life and Thought, Delhi: International Islamic Publisher, 1989.

Minhä, Akh. "Reorientasi Kajian Usul Fiqh," dalam Al-Jamiab:Journalof Ilamic Studies, No. 63/VI/1999.

Mudzhar, Atho. Membaca Gelombang Ijtihad: Antara Tradisi dan Liberasi. Yogyakarta: Titian Ilahi Press, 1998.

Nasution, Harun. Pembaharuan Dalam Islam: Sejarah, Pemikian, dan Gerakan, Jakarta: Bulan Bintang, 1994.

Sardar, Ziauddin. Jihad Intelektual: Merumuskan Parameter-parameter Sains, terj. A.E. Priyono. Surabaya: Risalah Gusti, 1998.

Schach, Joseph. "Problem of Modern Islamic Legislation," dalam IslamicLaw and Legal Theory, ed. Ian Edge. Aldershot: Dantmouth Publishing Company, 1996.

Syarifuddin, Amir. Pembaharuan Pemikiran dan Hukum Islam. Padang: Angkasa Raya, 1993.

Toha, Mahmud Muhammad. The Second Message of Islam. New York Syracuse University Press, 1989.

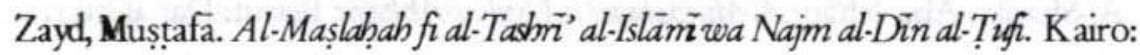
Där al-Fikr al-'Arabi, 1974. 